\title{
The Sisia Cave Bats of Bamenda, Cameroon
}

$\mathrm{T}$ he ever-growing population and extending towns in Cameroon have a very adverse effect on wildlife and its habitats. Early settlers in Bamenda, Cameroun, remember, with nostalgia, those good old days when Abakwa, or the 'Old Town Quarter' was the centre of town and the business hub of the region - when most of the present quarters were either farmland or virgin bush. These senior citizens recount how bushmeat was abundant and how farmland was plentiful and fertile.

Today the story is very different, as most of those farmlands and virgin bushland tracts have been built on as the urban population increases with more and more births and the influxes of opportunity-seekers from the rural areas. The wildlife that provided those people with bushmeat also disappeared with the virgin bushland. Sisia Quarters at the foot of Station Hill must have been one of those virgin bushland areas which were invaded by the human population. However, not all the animal wildlife of Sisia was forced to leave when the human beings came along any more than did some wild plants, despite the preponderance of human habitations and agriculture (Fig. 1).

Above the new residential area is a cave that is occupied by thousands of bats. This cave is beside a waterfall (Fig. 2) and is not only home to these bats but a wonderful natural sight as well. Most of the original vegetation around the entrance to the cave has been cut down to provide land for farming, and people have farmed right up to the very entrance to this cave. Most people in the vicinity do not understand why anyone would want to protect bats, or even know that they are quite beneficial, eating up mosquitoes and other harmful insects. In Cameroon, where the natural vegetation is being degraded at an alarming rate, these bats could help in the regeneration of some natural forests, as they live mainly on fruits such as figs, the seeds of which they help very much to propagate. Bats also help to pollinate many plants, including Bananas (Musa sapientum) and some cacti. For these reasons it is very important that those bats should be protected.

The Amateur Horticulturists Association (AHA) of Cameroon, which is based in Bamenda, is a non-profit

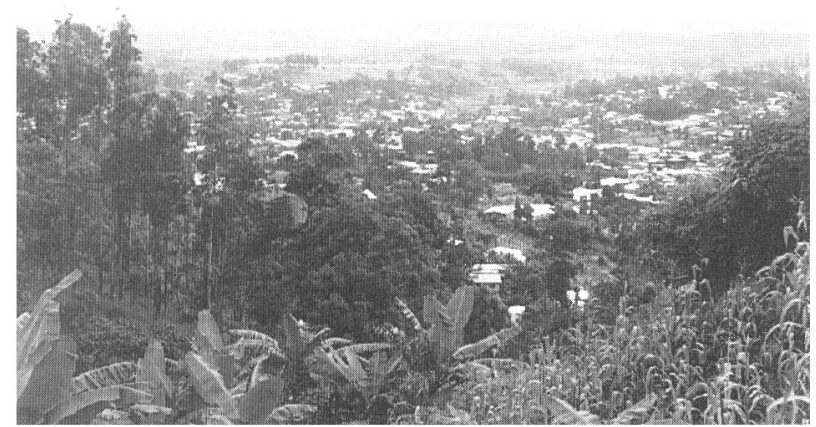

FiG. 1. Mainly cultivated area on hill in foreground with growing town on plain below. Plantain (Musa paradisiaca) on left with Eucalyptus trees behind and, on right, poor Maize (Zea mays) cultivation. Photo: J.Y. Musa, July 1994.

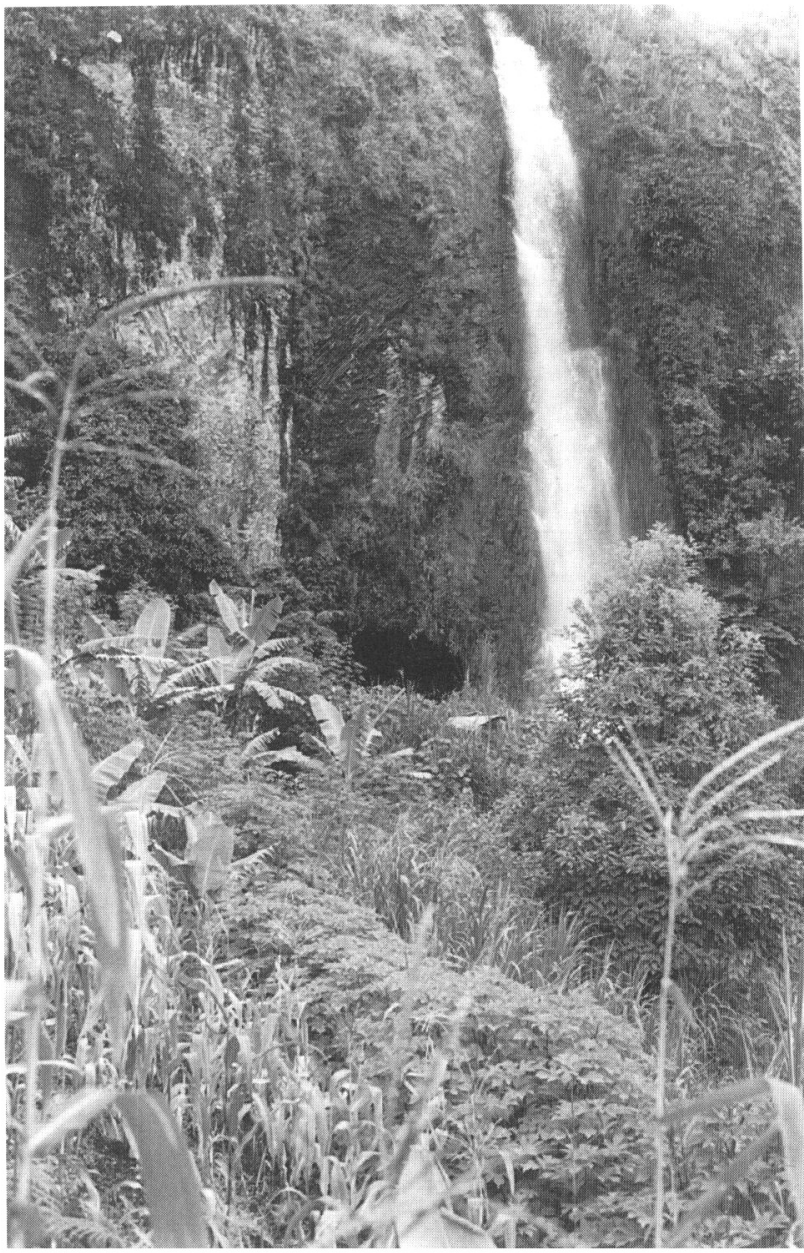

FIG. 2. Entrance to Sisia Cave seen over poor cultivated Maize and Plantain, etc., to left of waterfall in Bamenda, Cameroon. Photo: J.Y. Musa, July 1994.

NGO that promotes organic horticulture and addresses various environmental issues, including celebration of Biosphere Day and dissemination of its spirit. They are hoping soon to purchase the entrance into this Cave and to make this roosting area inaccessible to the public - particularly to poachers. Their modest budget does not permit them to make this purchase just at present, however, particularly following the current economic condition of Cameroon and the recent devaluation of the CFA Franc. Any assistance towards the realization of this project would be greatly appreciated and put to the best use. For further information contact the undersigned.

\section{JoHN Yuniwo Musa, Coordinator Editor of Newsletter \\ Amateur Horticulturists Association PO Box 5182 \\ Bamenda, Cameroon, West Africa.}

\section{The Foundation for Environmental Conservation: President's Report for the Year 1993 [updated]}

(Projects etc. generally in order of latest Annual Report, and updated to early Autumn 1994)

1. Environmental Conservation: - Quite gratuitously we continue to be sent submissions, especially of lon- ger papers, from practically all over the world, leading to an embarrassing backlog especially of 'full' papers 
and Short Communications even of those accepted for publication following specialist refereeing. In this, its twentieth year and volume, our quarterly Journal published 23 items in the Editorial Section, 31 'main' papers, 17 Short Communications \& Reports, 43 Notes, News \& Comments, 22 Reports of Conferences \& Meetings with, terminating the same section, 16 Notices of Important Prospects, and 22 Book Reviews with, at the end of that section, 8 Notices - in addition to cover features and the annual list of 'Other Books, etc., Received' during the year under review. Thus in this latest volume of our quarterly were published 174 separately-headed items, usually signed and almost all original, on a vast range of often leading environmental and/or conservational topics with some 108 illustrations and 74 tables. Requests for reprinting permission have been quite numerous and almost always granted, with occasional receipt of royalties from willing sources where books were to be widely for sale. The confidential Awards Committee terminated its notice of the year's 'Best Paper Prize(s)' (see 7 below) with the gratifying 'unanimous opinion that the Journal publishes papers of an exceptionally high standard and accomplishes its stated objectives with admirable success. Indeed, with its additional five regular sections, Environmental Conservation seems to us clearly the leading Journal in its wide and vital alliance of fields.' A second Supplement, covering the quinquennium 1989-93, of the Index of Titles and Authors, is in advanced preparation, and will be issued and sent to all registered subscribers to the Index, the entire set being available as long as stocks last for the inclusive price of US $\$ 40$ or SF60 (postage included).

2. International Conferences on Environmental Future:- Publication in December 1993 of the Proceedings book of nearly 600 pages of the fourth of these, entitled Surviving With The Biosphere, effectively terminated the President's responsibility for these pioneering Conferences, of which the first was held in Finland in 1971 (the year before 'Stockholm', to which it was an input*), the second in Iceland in 1977, the third in Scotland in 1987, and the fourth in Hungary in 1990. Each has led to a substantial volume - as would, doubtless, any further such ICEFs on more specialist topics such as 'Population and the Environment' following the United Nations' forthcoming International Conference on Population and Development (see 9 below).

3. World Council For The Biosphere:- The (10th annual) meeting proposed for Sonloup late in $1992 \mathrm{did}$ not take place as an earlier meeting in the Foundation's Headquarters (see Environmental Conservation, 19(4), p. 296, 1992), noting that as 'many of WCB's intended functions had been taken over by [other] bodies', it "should continue as a theme and title... on the notepaper of the Foundation for Environmental Conservation, but should cease separate functioning pending reconstitution as a rejuvenated body [as so much had changed since its establishment a decade earlier] with its own administration, budget, and duly revised

* As the chapters for our Proceedings book were edited, we took them one by one 'over the hill' to Maurice Strong in the Palais des Nations where he was preparing for 'Stockholm'.
Constitution'. Here we think particularly of such 'new bodies' as Earth Action 'designed to mobilize global public pressure' for necessary world-wide action, the Earth Council, the International Academy of the Environment, the International Green Cross, and the Commission on Global Governance. Meanwhile the residual functions of, or planned for, WCB [have been] taken on directly by FEC - particularly Biosphere Day and its prospective Fund, Prizes, and Clubs (see 6 below).

4. Environmental Monographs \& Symposia and Cambridge Studies in Environmental Policy:These have latterly remained largely in abeyance although the latter produced a successful paperback edition in 1992 of Caldwell's Between Two Worlds (which it had originally published in 1990) and is destined to resume activity with planned books soon. Decisions and likely action on these and several other matters await a promised visit from the Cambridge University Press Editorial Director (Science, Technology \& Medicine). Regarding a new series of inexpensive original paperbacks, see item 9 below.

5. World Who is Who and Does What in Environment \& Conservation:- This long-planned project is now at last proceeding actively towards hoped-for publication of a first instalment in the Winter of 1995-6 - to contain, we are striving to include, about one-third of the 3,000 aimed-at leading specialists, administrators, and benefactors, in either or both of the vital duality of fields involved. To date approaching 1,000 of those approved by the Foundation's confidential Awards Committee have responded acceptably and been sent drafts of their compiled biographies. Of these a large proportion have returned their corrected 'proofs' which will be edited in the coming months and then await publication. From the Sasakawa Foundation, of Tokyo, Japan, has been received a generous grant to cover the remaining costs of compilation spread over three years, which should enable the Foundation to become responsible for publication at least of the first instalment if no suitable publisher has been appointed. Meanwhile the ideal is sought of the wherewithal to send a copy of the first instalment in handy soft-bound form to each participating biographee - immediately to thank them for their participation, and more lastingly to "bring them together' effectively in a manner that ought to benefit the cause of the environmental/conservational movement.

6. Biosphere Day and Supporting Activities: - Starting on 21 September 1991, Biosphere Day has been celebrated each year on that same date, which was chosen as 'it heralds in the somewhat variable Autumnal Equinox of equal division of night and day in our Planet's Northern Hemisphere, and similarly the Spring Equinox in the Southern Hemisphere' (Environmental Conservation, 19(3), p. 194, 1992). To date Biosphere Day has been celebrated in the Foundation's Headquarters as well as by associates on probably all the normally-inhabited other continents. However, a deservedly less limited venue and more prominent sponsorship is sought for this initiative of which the objective 'is the quite vital need to remind the world, which means effectively all humanity everywhere, regularly each and every year, of the fragility of our only life-support, with the consequent necessity of 
safeguarding it looming as our foremost [indeed quintessential] human imperative' (ibid.). Biosphere Day was also chosen to come at an appropriate timegap following the springtime Earth Day and the summer Environment Day, and is planned to be supported by an endowment fund that should be sufficient to cover the award of an annual major Biosphere Prize and, hopefully, about six satellite prizes for advances in the main branches of scientific or allied endeavour involved - with due recognition not only of past achievement but also support to encourage ongoing work. Unforeseen circumstances (including the marriage of our Deputy Secretary on which we congratulate her most warmly) having so far impeded action on Biosphere Clubs (idem, 20(1), p. 3, $1993-$ see also 21(2), p. 97, 1994), it is gratifying to note that the idea has been adopted on a wider subject-basis in the successful luncheon-forums of the International Academy of The Environment.

7. Best Paper Prize(s):- Once again the Foundation's confidential Awards Committee had a difficult time in deciding on the 1993 winner(s), as the past year's volume included what, to our mind as well as pertinent Referees' reports, were some outstanding papers. Once again no fewer than four winning papers were chosen and certificates sent to their Authors, as recorded on page 2 of the Spring issue of our Journal (Environmental Conservation, 21(1), p. 2, 1994).

8. Human-caused Soil-ecological Changes and Their Effect on The Biosphere:- Apart from the promising link-up indicated in the Short Communication by Professor Vladimir N. Bashkin \& Dr Robert G. Bailey entitled 'Revision of Map of Ecoregions of the World (1992-5)', which we published early in the year in Environmental Conservation (20[1], pp. 75-6), there is little to report on, or news of, this major project owing to the state of affairs in Russia and difficulties of communication. [Items 9, 10, and 11, in our latest strictly annual report (idem, 19[1], pp. 79-80, 1992) it is much to be hoped are advancing in appropriate hands, being, respectively, Equable Use of The Biosphere's Commons [on which a chapter has been drafted for a forthcoming book], Environmental Impact Assessment Before Financing [on which a potential book has been drafted], and a much-needed World Collating Office of Environmental Education.]

9. Environmental Challenges:- This series of quicklyprinted, inexpensive 'original paperback readers by leaders', was started with the publication in mid-1993, jointly with the Energy and Environment Society of Pakistan, of a small volume of vi $+284 \mathrm{pp}$., with the theme-title of 'From Stockholm to Rio and Beyond'. Edited by Mohammad Nazim \& Nicholas Polunin, it has a Foreword by Dr Gro Harlem Brundtland and early chapters by Dr Mostafa K. Tolba, Dr Nafis Sadik, Mrs Birgitta Dahl, and Dr Arthur H. Westing, while included among later chapters are ones headed by Professor Bert Bolin, Dr Sandro M. Radicella, and Maurice F. Strong. The Price (including postage) from the Foundation Headquarters is US $\$ 12$ (for individuals) or US $\$ 20$ (for institutions). The second book in this series was published in time for the UN International Conference on Population and Development (ICPD), which took place in mid-September 1994 in Cairo, Egypt. Edited by Nicholas Polunin \& Mohammad Nazim, it is entitled Population and Global Security and has chapters by the SecretaryGeneral of ICPD (Dr Nafis Sadik), followed by others by Dr Norman Myers, Sir Shridath Ramphal, and Professor Clement A. Tisdell, and then one by three leaders in the World Bank. Thereafter follow five chapters on appropriate topics by leaders in the fields concerned, before the concluding two by HE Professor José Goldemberg (who was Brazil's Minister of Education and interim Minister of Environment at the time of UNCED), and Sir Martin Holdgate - the last to our delight holding out considerable 'Hopes for the Future'. This book being substantially longer and better printed on better paper than its predecessor, is priced at US $\$ 15$ for individuals and US \$25 for institutions - in both cases post-free from the Foundation.

10. Regarding further prospects for the future, in Oslo last September, on our way north to Troms $\emptyset$ to participate in the Fifth World Wilderness Congress, we visited the Norwegian Nobel Institute, where we were reassured that the Nobel Peace Prize Committee was coming around more and more to accepting the idea - which we have been pressing for four years in the belief that the bestowal of the Prize on an environmental or conservational person or body would do much to arouse public interest world-wide in the environmental movement - that their most prestigious Prize should be for environmental as well as other forms of peace. Such nominations have already been made and seriously considered, and now there is also a reopening of the initiative for a Nobel Memorial Prize for Ecology in the manner of that for Economics - which we hope can be a Pan-Scandinavian initiative but now think might be better styled for conservation (in the wide sense as including particularly that of Man's and Nature's environment) and possibly best indicated by such a phrase as 'Biosphere Conservation'. With the planned Biosphere Prize(s) (see 6 above), such a system would give each year, to a range of chosen environmentalists and conservationists, at once something of their due in public recognition, meaningful encouragements, and - even more important in times of financial restriction - useful 'windfalls' of help towards payment of the costs of their ongoing work.

11. Other items to report from last year are the establishment of an associated (apparently emulating our own) Foundation for Environmental Awareness, based on Baroda, India, and the planning (in collaboration with Dr Chi Yung Jim, Senior Lecturer in Biogeography and Soil Science in the University of Hong Kong) of a successor to Nicholas Polunin's Introduction to Plant Geography and Some Related Sciences, which has gone into various language editions but never been updated. The events involving invited participation in Mozambique (item 1 on p. 104 of Environmental Conservation, 20[2], 1993) and Singapore (ibid. bottom footnote), at Churchill, Manitoba, and near Tucson, Arizona (idem, p. 105), either did not take place in the end or were not implemented on our part for various reasons.

\section{Nicholas Polunin}

